\title{
Pengembangan Model Media Audio-Visual Untuk Meningkatkan Nilai-Nilai Agama dan Moral Anak Usia Dini Kota Bengkulu
}

\author{
Lydia Margaretha ${ }^{1}$, Dwi Nomi Pura ${ }^{2}$ \\ Fakultas Ilmu Pendidikan Universitas Dehasen Bengkulu, Jalan Meranti Raya No. 32 Sawah \\ Lebar Bengkulu. \\ 1 argarethalydia@gmail.com \\ 2miminao26@gmail.com
}

\begin{abstract}
This study aims to: (1) Design audio-visual media development that can enbance religious and moral values in learning; (2) Describe the effectiveness of using audio-visual media to improve religious and moral values. The subjects of this study were class $B$ teachers and children in the B grade of Bengkulu City. While the object of this research is andio-visual media as a learning medium in aspects of religious and moral values. This research was carried out using a "Research and Development" approach. Research and development aim to find and develop and validate a product, thus $R \& D$ research is longitudinal, research and development is also a method used to produce new products and test the effectiveness of these products. Based on the analysis used in this study, conclusions are taken: (1) Audio-visual media as learning media that can explain abstract religious and moral values to be concrete and attract children's attention so that they can increase religious and moral values child. (2) The audio-visual media developed is an effective alternative media as a learning media for aspects of religious and moral values to enhance the religious and moral values of Class $B$ $P A U D$ children. Increased religious values are significantly based on the results of t-test level significance 0.00 which is smaller than 5\%. The use of audio-visual media can improve children's morale after using audio-visual media is higher than before using audio-visual media.
\end{abstract}

Keywords: Audio Visual Media, Religious Values, Morals

\begin{abstract}
ABSTRAK
Penelitian ini bertujuan untuk : (1) Merancang Pengembangan Media audiovisual yang dapat meningkatkan nilai-nilai agama dan moral pada pembelajaran; (2) Mendeskripsikan efektivitas penggunaan media audio-visualuntuk meningkatkan nilai-nilai agama dan moral. Subyek penelitian ini adalah guru dan anak PAUD kelas B Kota Bengkulu. Sedangkan objek penelitian ini adalahberupa media audio-visual sebagai media pembelajaran aspek nilai-nilai agama dan moral. Penelitian ini dilakukan menggunakan pendekatan “ Penelitian Pengembangan" ( Research and Development). Penelitian dan
\end{abstract}


pengembangan bertujuan untuk menemukan dan mengembangkan dan memvalidasi suatu produk, dengan demikian penelitian $\mathrm{R} \& \mathrm{D}$ bersifat longitudinal, penelitian dan pengembangan juga suatu metode yang digunakan untuk menghasilkan produk baru dan menguji keefektifan produk tersebut. Berdasarkan analisis yang digunakan pada penelitian ini maka diambil kesimpulan: (1) Media audio-visual sebagai media pembelajaran yang dapat menjelaskan hal mengenai nilai-nilai agama dan moral yang bersifat abstrak menjadi kongkrit dan menarik perhatian anak sehingga dapat meningkatkan nilai-nilai agama dan moral anak. (2) Media audio-visual yang dikembangkan ini merupakan media alternatif yang efektif sebagai media pembelajaran aspek nilai-nilai agama dan moral untuk meningkatkan nilai-nilai agama dan moral anak PAUD Kelas B. Peningkatan nilai-nilai agama signifikan berdasarkan hasil uji-t taraf signifikasi 0,00 yang lebih kecil dari 5\%. Penggunaan media audiovisual dapat meningkatkan moral anak setelah menggunakan media audio-visual lebih tinggi dibanding sebelum menggunakan media audio-visual.

Kata kunci : Media Audio Visual, Nilai Agama, Moral

\section{PENDAHULUAN}

Pendidikan Anak Usia Dini (PAUD) sangat penting pelaksanaannya bahkan menjadi landasan kuat untuk mewujudkan generasi yang cerdas dan kuat. Taman Kanak-kanak merupakan bagian dari penyelenggaraan PAUD yang menitikberatkan pada peletakan dasar ke arah pertumbuhan dan perkembangan fisik. Kebugaran motorik halus dan kasar), kecerdasan (daya pikir, daya cipta, kecerdasan), sosial emosional (sikap dan perilaku serta agama), bahasa dan komunikasi, sesuai dengan keunikan dan tahap-tahap perkembangan yang dilalui oleh anak usia dini.

Perkembangan anak pada usia dini akan mempengaruhi perkembangan pada usia berikutnya. Rahimand Rahiem (2012:454) menjelaskan "Early childhood is a crucial stage in terms of a child's physical, intellectual, emotional and social development. Mental and physical abilities progress at an as to undingrate and avery high proportion of learning takes place from birth to age six years old." Usia dini adalah usia kritis pada perkembangan fisik, intelektual, dan sosial emosional. Rata-rata kemajuan kemampuan fisik dan rohani sangat pesat pada usia baru lahir hingga enam tahun. Kemajuan perkembangan tersebut diperoleh melalui hasil belajar dari lingkungan. Mengingat pentingnya keberadaan usia dini, maka diperlukan adanya pemberian stimulasi yang optimal pada usia tersebut, sehingga pertumbuhan dan perkembangan anak dapat berjalan sebagaimana mestinya.

Pendidikan Anak Usia Dini adalah pendidikan pertama yang dilalui anak dalam fase kehidupannya dan memiliki pengaruh yang besar terhadap kehidupan anak selanjutnya. Siraj and Blatchford (2009: 9) mengungkapkan "Early Childhood Education therefore has a major role 
top lay in achieving sustainable development." Pendidikan anak usia dini memiliki peran utama agar anak dapat mencapai perkembangan yang berkelanjutan.

Salah satu aspek yang wajib dikembangkan di PAUD yaitu aspek nilai-nilai agama dan moral. Pendidikan nilai-nilai agama dan moral pada program PAUD merupakan pondasi yang kokoh dan sangat penting keberadaannya, jika bersinar dan terpatri dengan baik dalam setiap insan sejak dini dapat dirasa keimanan dan moral dalam pendidikan selanjutnya.

Rendahnya mutu pendidikan di Indonesia menyebabkan rendahnya pula tingkat kualitas sumber daya manusianya sehingga dalam hal ini, pemerintah harus bisa meningkatkan kualitas pendidikan melalui pembelajaran-pembelajaran yang di dalamnya terdapat strategi untuk memberikan kemudahan pada anak dalam memahami dan mengaplikasikan pembelajaran yang ia peroleh dalam kehidupannya, khususnya pembelajaran yang terdapat pada pendidikan anak usia dini.

Upaya mendidik anak-anak yang menyenangkan perkara yang mudah, mendidik anakanak adalah upaya mewujudkan karakter manusia, manusialah yang nantinya akan membentuk masyarakat dan juga sebuah bangsa. Sebaliknya, karakter buruk akan menciptakan masyarakat dan bangsa yang menjadi bangsa yang buruk. Baik buruknya orangorang tergantung dari karakter atau moral manusianya. Dalam perkembangannya, dari mulai lahir ke bawah pendidikan dasar, anak-anak berada dalam masa keemasan, dan masa-masa kritis dalam tahapan kehidupan manusia, yang akan mendorong perkembangan anak selanjutnya. Masa-masa ini adalah masa yang tepat untuk meletakan dasar-dasar pengembangan.

Pengembangan nilai-nilai pelajaran sangat bermanfaat untuk anak sejak dini. Hal ini karena agar jiwanya bernilai-nilai dan norma yang sesuai dengan agama Islam. Sebagaimana yang disarankan oleh Zakiyah Daradjat: perkembangan agama pada anak sangat ditentukan oleh pendidikan dan pengalaman yang dilaluinya. Operasi dalam masa-masa pertumbuhan yang pertama (masa anak) dari umur 0-12 tahun. Seorang anak yang berada di masa kanakkanak tidak mendapat pendidikan agama dan tidak pula memiliki pengalaman keagamaan, kemudian ia akan menjadi orang dewasa yang akan menggunakan sikap negatif terhadap agama untuk mengatasi hal tersebut penulis mencoba menelaah pola belajar anak dengan media yang lebih menarik dan pemilihan model pembelajaran yang tepat sehingga proses kegiatan pembelajaran berjalan lebih efektif dan efisien, serta menyenangkan, dan dimungkinkan mencapai hasil yang optimal. Salah satu strategi pembelajaran adalah dengan menggunakan media audio visual. 
Berdasarkan latar belakang tersebut, penelitian ini memfokuskan pada upaya untuk mengembangkan salah satu media pembelajaran yaitu berupa media audio-visual untuk anak didik PAUD khususnya pada aspek perkembangan nilai-nilai agama dan moral. Hal ini sangat penting dilakukan karena dengan media audio-visual pembelajaran akan menambah dan memperdalam pengalaman serta motivasi belajar anak. Karena media audio-visual lebih mudah menyampaikan pesan dalam bentuk program yang menarik. Bagaimanakah pengembangan media audio-visual yang dapat meningkatkan nilai-nilai agama dan moral anak usia dini secara optimal. Bagaimana efektivitas media audio-visual hasil pengembangan dalam meningkatkan nilai-nilai agama dan moral Anak Usia Dini dalam pembelajaran. Masalah ini akan dibahas dalam tulisan ini.

\section{KAJIAN LITERATUR}

Belajar merupakan proses untuk meningkatkan kemampuan diri. Meyer (2008: 7) mengemukakan bahwa belajar merupakan perubahan pengetahuan pada diri siswa, dan perubahan itu terjadi karena hasil pengalaman. Dengan demikian belajar memiliki sifat perubahan pengetahuan secara permanen. Kreativitas siswa dapat dioptimalkan dengan menemukan alat multimedia baru dan membuat materi dalam gaya yang tersedia bagi mereka melalui permainan, $\mathrm{CD}$, dan televisi. Meyer mengemukakan bahwa belajar memiliki tiga pokok pengertian yait : 1) Belajar adalah terjadinya perubahan yang meliputi aspek kognitif, afektif dan psikomotor, 2) Belajar mencakup perubahan pengetahuan yang direfleksikan dalam perubahan tingkah laku, 3) Belajar tergantung pada pengalaman dari pelajar atau siswa. Perubahan aspek kognitif menunjuk pada capaian pengetahuan yang dikuasai oleh peserta didik.

Pembelajaran merupakan kerangka konseptual yang melukiskan prosedur yang sistematis dalam mengorganisasikan pengalaman belajar untuk mencapai tujuan belajar tertentu, dan berfungsi sebagai pedoman bagi para perancang pembelajaran dan para pengajar dalam merencanakan dan melaksanakan aktivitas pembelajaran. Proses pembelajaran merupakan kegiatan yang terencana secara sistematis. Proses pembelajaran memiliki dampak yaitu hasil belajar yang dicapai langsung dengan cara mengarahkan para pembelajar pada tujuan yang diharapkan, sedangkan dampak lainnya yaitu dampak pengiring yang berupa hasil belajar lainnya yang dihasilkan oleh suatu proses pembelajaran sebagai akibat terciptanya suasana belajar yang dialami langsung oleh para pembelajar tanpa pengarahan langsungdari pengajar. Hamalik (2010: 57-66) mendefinisikan pembelajaran 
sebagai suatu kombinasi yang tersusun meliputi unsur - unsur manusiawi, material, fasilitas, perlengkapan dan prosedur yang saling mempengaruhi untuk mencapai tujuan pembelajaran, sehingga pembelajaran merupakan suatu sistem yang melibatkan sub sistem dan masingmasing saling mempengaruhi. Dalam konsep pembelajaran dikemukakan bahwa pembelajaran merupakan persiapan di masa depan, pembelajaran merupakan proses penyampaian pengetahuan, tujuan pembelajaran adalah penguasaan pengetahuan. Pembelajaran mengandung tiga ciri yaitu perencanaan, ketergantungan dan tujuan. Perencanaan merupakan penataan ketenagaan, material, dan prosedur. Sedangkan ketergantungan mengandung maksud antara unsur - unsur dalam pembelajaran saling bergantung satu dengan yang lain.

Menurut NAEYC (National Association for The Education Young Children), anak usia dini atau early childhood adalah anak yang berada pada usia nol hingga delapan tahun. Mursid (2015: 14) menjelaskan bahwa anak usia dini yaitu kelompok manusia yang berusia 0-8 tahun. Beliau menjelaskan bahwa anak usia dini adalah kelompok anak yang berada dalam proses pertumbuhan dan perkembangan yang bersifat unik, dalam arti memiliki pola pertumbuhan dan perkembangan (koordinasi motorik halus dan kasar), intelegensi (daya pikir, daya cipta, kecerdasan emosi dan kecerdasan spiritual), sosial emosional (sikap dan perilaku serta agama), bahasa dan komunikasi yang khusus sesuai dengan tingkat pertumbuhan dan perkembangan anak.

Media pembelajaran menurut Briggs adalah sarana untuk memberikan perangsang bagi pelajar supaya proses belajar terjadi. Media adalah segala bentuk dan saluran untuk proses transmisi. Dalam lingkup pendididkan media adalah salah satu benda yang dapat dimanipulasikan, dilihat dan didengar, dibaca atau dibicarakan beserta instrumen yang dipergunakan untuk kegiatan pendidikan (Okta, 2017: 4). Nilai-nilai agama dan moral merupakan salah satu aspek yang harus dikembangkan dalam diri anak khususnya di PAUD Kota Bengkulu. Nilai- nilai agama adalah kepercayaan pada ketentuan hidup yang teratur, moral berarti adat-istiadat, kebiasaan, peraturan, nilai atau tata cara kehidupan.

Peneliti akan menjelaskan kecocokan media pembelajaran audio-visual pada perkembangan moral anak. Penelitian ini dibatasi pada materi pembelajaran tentang moral khususnya pada kompetensi dasar yang mendeskripsikan sikap disiplin dan bertanggung jawab. Azhar menjelaskan bahwa: "media audio-visual adalah cara untuk menghasilkan atau menyampaikan materi dengan menggunakan mesin-mesin mekanis dan elektronik untuk menyajikan pesan-pesan audio-visual sehingga pengajaran yang dilakukan melalui audio-visual adalah sebuah produksi dan penggunaan materi yang penyerapannya melalui pandangan dan 
pendengaran serta tidak seluruhnya tergantung kepada pemahaman kata atau simbol-simbol yang serupa. Hal ini senada dengan pendapat Arsyad dalam Khadijah bahwa: "media audiovisual adalah perantara yang dapat menyampaikan pesan kepada peserta didik melalui dilihat dan didengar (Arsyad, 2009: 31).

Pembelajaran seharusnya dapat menggunakan media yang dapat memperlancar komunikasi dalam prosesnya, dan menggunakan sarana yang dapat membuat peserta didik nyaman dan dengan mudah memahaminya, sehingga pembelajaran dapat mencapai tujuan secara maksimal.Penggunaan teknologi dalam pembelajaran pada masa sekarang (modern), tentunya mempunyai perbedaan dalam wujudnya. Media pembelajaran berbasis teknologi dewasa ini sangat maju dan cukup variatif, masih terbuka untuk lebih canggih masa pada yang akan datang.

Media pembelajaran audio-visual dilakukan agar anak lebih terarah dalam mencari dan menemukan informasi tentang perilaku moral yang berhubungan dengan sikap disiplin dan bertanggung jawab dari berbagai macam media audio-visual di antaranya film dan video.

\section{METODE}

Penelitian ini dilakukan menggunakan pendekatan "penelitian dan pengembangan" (reasearch and development). Menurut Richey dan Klien penelitian dan pengembangan adalah salah satu jenis penelitian pragmatik, yang digunakan untuk menguji teori dan memvalidasi praktik yang terus menerus dilakukan secara esensial melalui tradisi yang tidak menantang (Emzir, 2011: 263). Suatu cara untuk mendapatkan prosedur-prosedur, teknik-teknik dan peralatan-peralatan baru yang didasarkan pada suatu analisis metodik tentang kasus-kasus spesifik.

Penelitian dan pengembangan bertujuan untuk menemukan, mengembangkan dan memvalidasi suatu produk, dengan demikian penelitian R\&D bersifat longitudinal. Penelitian dan pengembangan yaitu suatu metode yang digunakan untuk menghasilkan produk baru dan menguji keefektifan produk tersebut (Sugiyono, 2014: 297). Kedua pendapat tersebut diperkuat oleh pendapat Sukmadinata yang menyatakan " penelitian dan pengembangan adalah suatu proses/langkah-langkah untuk mengembangkan suatu produk dan menyempurnakan produk yang telah ada, yang dapat dipertanggungjawabkan" (Paidi, 2012: 63)

Penelitian pengembangan dapat dilakukan di berbagai bidang termasuk bidang pendidikan, penelitian ini akan menghasilkan materi, media, alat dan atau strategi pembelajaran, alat evaluasi dan sebagainya digunakan untuk mengatasi masalah pendidikan Kindergarten, Vol. 2, No. 2, November 2019, Hal. 167-179 
meningkatkan efektivitas proses belajar mengajar di kelas maupun di laboraturium dan bukan untuk menguji teori ( Paidi, 2012: 64).

Metode penelitian yang digunakan adalah penelitian pengembangan yang terdiri dari 3 komponen utama yaitu : studi pendahuluan, pengembangan dan pengujian produk. Selanjutnya ditambahkan pengujian deskriptif untuk melihat keefektifan penggunaan media yang dikembangkan nilai-nilai agama dan moral anak serta untuk mengetahui tingkat signifikan sebelum dan sesudah penggunaan media terhadap nilai-nilai agama dan moral anak.

Dalam penelitian dan pengembangan ini mengacu pada prosedur yang ditawarkan oleh Sugiyono dengan modifikasi model ADDIE. Tahap I : Studi pendahuluan pada tahap pendahuluan dilakukan analisis kebutuhan dengan studi literatur yang berkaitan dengan konsep dan teori media audio-visual pembelajaran serta pembelajaran khususnya pada aspek perkembangan nilai-nilai agama dan moral. Berdasarkan studi literatur didapatkan bahwa pemanfaatan media khususnya media audio-visual pembelajaran sangat penting dilakukan untuk mencapai tujuan pembelajaran yang diinginkan. Dengan pemanfaatan media audiovisual pembelajaran, pesan pembelajaran yang disampaikan dapat dengan mudah pemanfaatan media untuk pembelajaran akan menumbuhkan motivasi peserta didik dalam belajar.

Tahap II : Tahap pengembangan model. Model pengembangan media audio-visual pembelajaran ini menerapkan model prosedural. Model prosedural adalah model yang bersifat deskriptif, yaitu menggariskan langkah-langkah yang harus diikuti untuk menghasilkan produk. Model prosedural yang diadopsi dalam pengembangan media audiovisual pembelajaran ini adalah model ADDIE. Tahapan yang dilakukan yaitu : 1) Analisis yaitu menganalisis dan menentukan kebutuhan media dan konten pembelajaran melalui studi literatur dan studi lapangan. Dalam hal ini media yang dikembangkan yaitu media audio-visual pembelajaran, sedangkan konten media audio-visual pembelajarannya yaitu pada aspek perkembangan nilai-nilai Agama dan Moral, 2) Desain yaitu menyusun draft model media audio-visual pembelajaran aspek perkembangan nilai-nilai agama dan moral berdasarkan analisis kebutuhan yang sudah merujuk pada unitopik bahasan atau materi yaitu aspek perkembangan nilai-nilai agama dan moral dengan terlebih dahulu melalui pengkajian oleh ahli media audio-visual Kepala Sekolah dan Guru PAUD. Komponen pada draft model yang disusun meliputi garis besar isi media audio-visual aspek perkembangan nilai-nilai agama dan Moral, naskah media audio-visual aspek perkembangan nilai-nilai agama dan moral danbahan penyerta, 3) Pengembangan yaitu proses memproduksi atau merekam media audio- 
visual aspek perkembangan nilai-nilai agama dan moral kemudian dilanjutkan dengan menguji coba terbatas produk pada PAUD Sehati dan hasilnya sebagai petunjuk serta panduan merevisi produk.

Dalam ujicoba terbatas yang dilakukan yaitu guru memperdengarkan program pada anak PAUD, kemudian setelah selesai dilanjutkan dengan pengisian kuesioner oleh anak dan guru setelah selesai proses mendengarkan program. Setelah keseluruhan proses ujicoba terbatas selesai sampai pada merevisi, kemudian langkah selanjutnya dilakukan ujicoba media audio-visual pembelajaran aspek perkembangan nilai-nilai agama dan moral secara luas yaitu pada dua PAUD di Kota Bengkulu yaitu PAUD Dahlia dan PAUD Sehati yang hasilnya untuk panduan penyempurnaan serta justifikasi keefektifan awal produk. Strategi yang digunakan dalam ujicoba diperluas yaitu pada awalnya dua sekolah terpilih sebelum proses pembelajaran dilakukan pre-test tentang perkembangan nilai-nilai agama dan moral terhadap anak PAUD oleh guru masing-masing, setelah pre-test selesai kemudian dilakukan pembelajaran dengan memanfaatkan produk media audio-visual pembelajaran aspek perkembangan nilai-nilai agama dan moral.

Setelah pemanfatan selesai dilanjutkan dengan pengukuran berupa post-test terhadap anak mengenai perkembangan nilai-nilai agama dan moral melalui kuesioner seperti pada pretest. Hasil pre-test dan post-test kemudian dianalisis secara statistik kemudian dibandingkan masing - masing PAUD antara hasil pre-test dengan hasil post-test dengan Uji-T untuk mengetahui perbedaannya. Jika perbandingan hasil pre-test dengan post-test pada PAUD terdapat perbedaan yang signifikan maka produk mendapatkan justifikasi keefektifan awal, namun jika perbedaannya tidak signifikan maka produk perlu dilakukan evaluasi lagi, 4) Implementasi yaitu melakukan evaluasi atau pengujian produk media audio pembelajaran. Pada tahap ini model media audio-visual pembelajaran aspek perkembangan nilai-nilai agama dan moral diujikan perkembangan nilai-nilai agama dan moral untuk mengetahui keefektifan produk. Pengujian dilakukan dengan menerapkan penelitian eksperimen yang dilakukan terhadap dua PAUD di wilayah Kota Bengkulu. Dua PAUD tersebut yaitu terdiri dari satu PAUD sebagai PAUD kontrol dan satu PAUD sebagai PAUD eksperimen. Berlaku sebagai sekolah kontrol yaitu PAUD Gemilang dan PAUD eksperimen yaitu PAUD Dahlia dan PAUD Sehati. Pada PAUD eksperimen, strategi yang digunakan yaitu pembelajaran dengan memanfaatkan program pada anak PAUD. Teknis pelaksanaannya yaitu sebelum pembelajaran dimulai dilakukan pengukuran dengan angket tentang sikap perkembangan nilai-nilai agama dan moral anak, setelah selesai dilanjutkan pembelajaran aspek perkembangan nilai-nilai agama dan moral dengan memanfaatkan program, setelah selesai 
pembelajaran dengan pemanfaatan program kemudian diukur lagi sikap siswa dengan angket untuk mengetahui hasil akhirnya. Sedangkan sekolah kontrol menerapkan pembelajaran aspek perkembangan nilai-nilai agama dan moral seperti sebelumnya tanpa ada perlakuan dalam pembelajaran dengan memanfaatkan pemutaran program media audio-visual aspek perkembangan nilai-nilai agama dan moral.

Dalam pelaksanaan pembelajaran pada sekolah kontrol diawali dengan pre-test yaitu dengan mengisi angket bagi anak tentang perkembangan nilai-nilai agama dan moral, setelah selesai kemudian dilakukan pembelajaran sikap perkembangan nilai-nilai agama dan moral seperti pembelajaran yang biasa dilakukan oleh guru, setelah pembelajaran selesai kemudian dilakukan kembali pengukuran perkembangan nilai-nilai agama dan moral anak dengan mengisi angket seperti pada waktu awal pembelajaran dengan dibantu oleh guru dan peneliti, 5) Evaluasi yaitu melakukan Setelah data terkumpul lengkap dari implementasi kemudian dilakukan evaluasi dengan menganalisisstatistik dengan Uji - T. Hasil dari pengukuran sekolah eksperimen yang memanfaatkan media audio-visual aspek perkembangan nilai-nilai agama dan moral dalam pembelajaran kemudian dibandingkan dengan hasil dari pengukuran sekolah kontrol yang tidak diberi perlakuan pemutaran program dalam pembelajaran. Dari hasil evaluasi akan didapat hasil akhir tentang keefektifan model yang dikembangkan.

Setelah desain media audio pembelajaran aspek perkembangan nilai-nilai agama dan moral tersusun maka langkah selanjutnya dilakukan validasi desain dengan cara uji ahli. Uji ahli dilakukan terhadap isi materi media audio-visual pembelajaran aspek perkembangan nilainilai agama dan moral dan sisi kemediaannya. Revisi desain yaitu melakukan evaluasi dan revisi terhadap komponen dan bahan dalam proses pengembangan Media Audio-Visual yang meliputi bahan penyerta dan media audio-visual berdasarkan masukan dan arahan validasi dari ahli materi dan ahli media . Proses revisi dan perbaikan dilakukan secara on-going yaitu pada proses pembuatan dan penyusunan sudah dilakukan pengkajian oleh ahli materi dan ahli media, dan jika terdapat komponen yang harus diperbaiki dan revisi maka pengembanglangsung melakukan revisi dan perbaikan sehingga hasil akhir yang dikembangkan sudah sesuai dan sudah tervalidasi oleh ahli.

Desain uji coba produk media audio-visual pembelajaran aspek perkembangan nilainilai agama dan moral. Perkembangan nilai-nilai agama dan moral ini dilakukan dua tahap yaitu uji coba lapangan terbatas dan ujicoba lapangan yang diperluas. Uji coba lapangan terbatas dilakukan pada anak PAUD Kelas B beserta guru kelas PAUD Gemilang Kota Bengkulu. Strategi pada ujicoba terbatas yaitu pemanfaatan produk media audio-visual pada Kindergarten, Vol. 2, No. 2, November 2019, Hal. 167-179 
kelas B oleh guru kelas, kemudian dilanjutkan pengisian angket oleh guru dan anak (Pengisian angket anak dibantu guru dan peneliti) untuk memberikan penilaian terhadap kemenarikan serta kesesuaian produk.

Pada ujicoba terbatas ini, angket yang digunakan untuk mengumpulkan data kemenarikan produk audio-visual menggunakan angket penilaian standar. Setelah dilakukan ujicoba terbatas dan menghasilkan data maka langkah selanjutnya menganalisis data tersebut untuk mendapatkan masukan perbaikan produk jika ada, namun jika tidak ditemukan perubahan maka dilanjutkan langkah berikutnya yaitu uji coba diperluas. Uji coba lapangan diperluas dilakukan pada dua PAUD yaitu PAUD Dahlia dan PAUD Sehati di wilayah Kota Bengkulu di luar sekolah yang menjadi lokasi analisis kebutuhan uji coba terbatas dan uji instrumen. Strategi yang digunakan dalam ujicoba diperluas yaitu pada awal pembelajaran di dua sekolah terpilih dilakukan pre-test terhadap anak kelas B oleh guru kelas masing-masing, setelah pre-test selesai kemudian dilakukan pembelajaran dengan memanfaatkan produk media audio-visual pembelajaran aspek perkembangan nilai-nilai agama dan moral. Setelah pemanfaatan selesai maka kemudian dilanjutkan lagi pengukuran terhadap anak melalui kuesioner seperti pada pre-test. Hasil pretestdan post-test kemudian dianalisis secara statistik kemudian dibandingkan masing-masing sekolah antara hasil pre-test dengan hasil post-test tentang perkembangan nilai dan moral anak dengan Uji-T untuk mengetahui perbedaan hasil test sebelum dengan sesudah pemutaran produk media andio-visual pembelajaran aspek perkembangan nilai-nilai agama dan moral.

Lokasi uji coba tahap pengembangan ini dilakukan pada tiga PAUD di wilayah kota Bengkulu yaitu PAUD Gemilang di Teluk Sepang Kota Bengkulu sebagai lokasi ujicoba terbatas, sedangkan PAUD Dahlia di Lingkar timur Kota Bengkulu dan PAUD Sehati di Betungan Kota Bengkulu sebagai lokasi uji coba diperluas dengan pertimbangan bahwa sekolah di wilayah tersebut sangat minim ketersediaan media pembelajaran khususnya media audio-visual pembelajaran aspek perkembangan nilai-nilai agama dan moral yang sama sekali tidak dimiliki. Di samping itu secara geografis berada jauh dari pusat kota Bengkulu sehingga keterjangkauan teknologi dan media pembelajaran sangat kurang. Sedangkan subyek uji coba terbatas yaitu anak PAUD Kelas B dan guru kelas, untuk uji coba diperluas subyeknya adalah anak PAUD Kelas B dan juga guru kelas. Siswa yang dilibatkan yaitu seluruh anak PAUD Kelas B yang masing-masing sekolah anak PAUD Kelas B berjumlah 30 siswa, sedangkan guru berjumlah 3 orang yaitu masing-masing sekolah lokasi uji coba 1 orang guru PAUD Kelas B. Anak PAUD kelas B dipilih karena di samping bagian dari kelas tinggi, secara mental psikologis siswa PAUD kelas B lebih matang dibandingkan anak 
PAUD kelas A. Peran guru sekaligus sebagai pemakai media andio-visual aspek perkembangan nilai-nilai agama dan moral untuk proses pembelajaran di kelas. Selama proses pembelajaran berlangsung, peneliti berperan sebagai pengamat. Teknik pemilihan subyek yaitu dengan metode purposive. Metode purposive merupakan teknik penentuan sampel dengan pertimbangan tertentu dan tepat digunakan untuk penelitian kualitatif (Sugiyono, 2011: 124).

Dalam penelitian ini jenis datanya yaitu data kuantitatif dan data kualitatif. Data kuantitatif berupa hasil analisis dari instrumen perkembangan nilai-nilai agama dan moral anak, sedangkan data kualitatif berupa deskripsi dari analisispengamatan, wawancara dan diskusi. Data kualitatif didapatkan dari hasil ujicoba terbatas produk media audio-visual pembelajaran aspek perkembangan nilai-nilai agama dan moral. Sedangkan data kuantitatif didapatkan dari hasil ujicoba diperluas produk media audio-visual pembelajaran aspek perkembangan nilai-nilai agama dan moral. Data penelitian tahap pengembangan dalam ujicoba terbatas yaitu berupa informasi empiric mengenai kemenarikan dan ketepatan materi produk media audio-visual aspek perkembangan nilai-nilai agama dan moral. Sedangkan data ujicoba diperluas berupa data skor angket sikap kedisiplinan siswa yang meliputi skor pre-test dan skor post-test.

\section{HASIL DAN PEMBAHASAN}

Media hasil pengembangan merupakan media interaktif sebagai sumber belajar aspek nilai-nilai agama dan moral pada anak PAUD kelas B. Media audio-visual ini merupakan media pembelajaran berbentuk video interaktif sehingga dalam penggunaannya memerlukan Laptop atau Komputer dengan spesifikasi minimal: 1) Prosesor intel Pentium IV 3.0 GHz , 2) RAM 512 MB, 3) Windows XP, 4) Memiliki aplikasi flash player, 5) Aplikasi dalam bentuk exe sehingga bias dioperasikan dengan cara stand alone dan dapat di tampilkan langsung secara visual, beserta pengeras suaranya.

Media hasil pengembangan audio-visual merupakan suatu media pembelajaran interaktif yang melibatkan siswa secara langsung dalam penggunaannya.Keterlibatan siswa secara langsung dapat melibatkan gambar dan suara sehingga siswa dapat memiliki pengalamanpengalaman pembelajaran yang lebih baik. Jika siswa memiliki pengalaman lebih baik dalam dalam proses pembelajaran untuk meningkatkan nilai-nilai agama dan moral siswa, ini sesuai dengan hasil penelitian yang dilakukan Komariah (2014:229) media interaktif sangat efektif sebagai media pembelajaran sebagai media pembelajaran untuk meningkatkan hasil belajar siswa. Sehingga dengan penggunaan audio-visual sebagai media pembelajaran interaktif sangat 
efektif digunakan untuk meningkatkan nilai-nilai agama dan moral siswa PAUD di Kota Bengkulu.

Proses pembelajaran dalam aspek nilai-nilai agama dan moral yang menggunakan audio-visual pada PAUD di Kota Bengkulu yang dapat melibatkan siswa secara langsung dalam penggunaannya, siswa tidak merasa bosan mengikuti proses pembelajaran sehingga nilai-nilai agama dan moral siswa dapat meningkat. Siswa melakukan pembelajaran tanpa adanya tekanan dan terus bersemangat mengikuti proses pembelajaran, media audio-visual sangat efektif untuk meningkatkan nilai-nilai agama dan moral siswa.

\section{KESIMPULAN}

Berdasarkan analisis yang digunakan pada penelitian ini maka diambil kesimpulan: (1) Media audio-visual sebagai media pembelajaran yang dapat menjelaskan hal mengenai nilainilai agama dan moral yang bersifat abstrak menjadi kongkrit dan menarik perhatian anak sehingga dapat meningkatkan nilai-nilai agama dan moral anak. (2) Media audio-visual yang dikembangkan ini merupakan media alternatif yang efektif sebagai media pembelajaran aspek nilai-nilai agama dan moral untuk meningkatkan nilai-nilai agama dan moral anak PAUD Kelas B. Peningkatan nilai-nilai agama signifikan berdasarkan hasil uji-t taraf signifikasi 0,00 yang lebih kecil dari 5\%. Penggunaan media audio-visual dapat meningkatkan moral anak setelah menggunakan media audio-visual lebih tinggi dibanding sebelum menggunakan media audio-visual.

\section{REFERENSI}

Arsyad, Azhar. 2009. Media Pembelajaran, Jakarta: PT Raja Grafindo Persada.

Emzir. 2011. Metodelogi Penelitian Pendidikan Kualitatif dan Kuantitatif.Jakarta: PT. Rajawali Pers. Hamalik, Oerman. 2010. Kurikulum dan Pembelajaran. Jakarta : Bumi Aksara.

Meyer, Richard. 2008. Learning and Instruction. New Jersey : PearsonEducation Inc.

Mursid. 2015. Belajar dan Pembelajaran PAUD. Bandung: Remaja Rosdakarya.

Okta, Putu, Arya, Gde. 2017. Media dan Multemedia Pembelajaran. Yogyakarta: Depiblish.

Paidi. 2012. Pengembangan Pembelajaran Dengan Moodie Untuk Meningkatkan Hasi Belajar (Studi Pada Mata Pelajaran Produktif Standar Kompetensi Keselamatan, Kesehatan Kerja dan Ungkungan Hidup di SMK Propinsi Bengkulu); Bengkulu: FKIP Universitas Bengkulu. 
Rahim, Husni and Rahiem, Maila. Dinia,Husni.2012 . The Use Of Stories As Moral Education For Young Children.International Journal of Social Science and Humanity, Vol. 2, No. 6, November 2012.

Siraj, jhon and Blatchford.2009. Editorial: EducationforSustainable Developmentin Early Childhood. International Journal of Early Childhood, Vol. 41, No. 2, 2009.https://link.springer.com/article/10.1007\%2FBF03168875?LI=true

Sugiyono. (2011). Metode Penelitian Pendidikan Pendekatan Kuantitatif,kualitatif dan R\&D. Bandung : Alfabeta. 